\title{
Differential effect of acetyl-I-carnitine on open field behaviour in young and old rats
}

Citation for published version (APA):

Blokland, A., Raaijmakers, W., van der Staay, F. J., \& Jolles, J. (1990). Differential effect of acetyl-Icarnitine on open field behaviour in young and old rats. Physiology \& Behavior, 47(4), 783-785. https://doi.org/10.1016/0031-9384(90)90096-M

Document status and date:

Published: 01/01/1990

DOI:

10.1016/0031-9384(90)90096-M

Document Version:

Publisher's PDF, also known as Version of record

\section{Please check the document version of this publication:}

- A submitted manuscript is the version of the article upon submission and before peer-review. There can be important differences between the submitted version and the official published version of record.

People interested in the research are advised to contact the author for the final version of the publication, or visit the DOI to the publisher's website.

- The final author version and the galley proof are versions of the publication after peer review.

- The final published version features the final layout of the paper including the volume, issue and page numbers.

Link to publication

\footnotetext{
General rights rights.

- You may freely distribute the URL identifying the publication in the public portal. please follow below link for the End User Agreement:

www.umlib.nl/taverne-license

Take down policy

If you believe that this document breaches copyright please contact us at:

repository@maastrichtuniversity.nl

providing details and we will investigate your claim.
}

Copyright and moral rights for the publications made accessible in the public portal are retained by the authors and/or other copyright owners and it is a condition of accessing publications that users recognise and abide by the legal requirements associated with these

- Users may download and print one copy of any publication from the public portal for the purpose of private study or research.

- You may not further distribute the material or use it for any profit-making activity or commercial gain

If the publication is distributed under the terms of Article $25 \mathrm{fa}$ of the Dutch Copyright Act, indicated by the "Taverne" license above, 


\title{
BRIEF COMMUNICATION
}

\section{Differential Effect of Acetyl-1-Carnitine on Open Field Behavior in Young and Old Rats}

\author{
ARJAN BLOKLAND, WIJNAND RAAIJMAKERS, \\ F. JOSEF WAN DER STAAY AND JELLEMER JOLLES \\ Department of Neuropsychology and Psychobiology. University of Limburg \\ P.O. Box 616, 6200 MD Maastricht, The Netherlands
}

Received 5 July 1989

\begin{abstract}
BLOKLAND, A. W. RAAIJMAKERS, F. J. VAN DER STAAY AND J, JOLLES. Differential effect of arengl-carminine on open field behavior in young and old rats. PHYSIOL BEHAV 47(4) 783-785, 1990. - Acety-1-carnitine (ALCAR) exerts antiaging effects with regard to various physiological and neurochemical measures in rats. In this study we evaluated the effect of achronic treatment with ALCAR (6 weeks, $50 \mathrm{mg} / \mathrm{kg} / \mathrm{day}$ ) on the open field behawior of 5 -month-old and 26 -monthwold male Wistar rats. Old rats defecated more, made fewer crossings, and spent more time in the comer squares. However, it is difficult to interpret these findings in terms of an increase in emotional reactivity with age because locomotor performance generally has been found to be impaired in old rats. Consequently, treatment effects were analysed within age groups. ALCAR had no effect in young rats, but the old ALCAR-treated rats ambulated less and spent more time in the comer squares than the old control rats. We have interpreted this in terms of at eahanced emotional reactivity of old ALCAR-treated rats.
\end{abstract}

Acetyl-iarnitine Open field Enotional reactivity Age differences

VARIOUS nootropic substances have been developed in the search for a potential pharmacological treatment of cognitive disturbances in elderly subjects. One of these substances is acetyl-1-carnitine (ALCAR). ALCAR is the acetyl derivate of carnitine, a naturally occurring substance which plays an important role in the energy and lipid metabolism of cells $(4,5)$. As ALCAR can cross the blood-brain barrier, it could affect brain cells directily [see (1)].

Chronic ALCAR ireatment is reported to exert antiaging effects as it prevents several age-associated neuroanatomical and neurochenical changes, particularly in the hippocampus $(2,4)$. Another study has shown that the control of adrenocortical responsiveness is improved in aged ALCAR-treated rats (1). This finding is consistent with the anatomical and functional preservation of hippocampal glucocorticoid receptors found in old rats chronically treated with ALCAR (1). Furthermore, chronic ALCAR treatment has been shown to improve discrimination learning in 19-monthold rats compared to untreated controls (8).

ALCAR treatment increases the levels of caminine and ALCAR in the brain. It has been suggested that basal forebrain cholinergio neurons are activated by the increase in high-affinity choline uptake activity in cortical and hippocampal but not striatal syraplosomes (4).

The effects of ALCAR on basal aspects of behavior are not clear. Drago and coworkers (5) found that young rats showed more ambulation and reared more frequently in an open field (OF) sifter acute injections of ALCAR (1 mg/kg, IP) than young untreated rats. Increased ambulation is commonly interpreted as reflecting a lower level of emotionality $(3,16)$. We decided to study the effects of chronic ALCAR treatment on open field behavior. Besides increased ambulation (number of squares crossed) (10), fewer boli (9) and a decreased occupancy of corner squares (16) were taken to indicate lower" "emotional reactivity." An increased "emotional reactivity," on the other hand, should express itself in changes in these measures in the opposite direction.

Both young and old rats were used in the present study. In view of the presumed nootropic activity of $A L C A R$, it is of interest to study the effects of chronic ALCAR on OF behavior in old tats. An age-associated decrease in locomotor activity (18) maly inter. fere with the interpretation of the expected lower ambulation of old rats in the OF. Schuuman and Traber (15) reported a decrease in ambulation of about 30 percent between young ( $3-4$ months) and

\footnotetext{
${ }^{1}$ Requests for reprints should be addressed to W. G. M. Raaijmakers
} 
aged (21-25 months) rats of the same strain used in this study. Since there are no relevant validation studies, it is not certain whether an age-related decline of OF ambulation represents a fall in emotional reactivity, in arousal (15), or in motor skills (7). We assume, however, that the of measures are valid to detect ALCAR-induced emotional changes within age groups, which is the main objective of the present study. Futhermore, we hypothesized that aged rats would be less active than young rats as reported by others $(7,15,18)$. We compared the untreated age groups to test this hypothesis.

\section{METHOD}

\section{Animals}

We used male random-bred Wistar rats [Bor:WISW(SPFCpb), Winkelmann, Borchen, West Germany] from two shipments, each consisting of eight young (2-monthold) and eight old (23monthwold) animals. Rats from each shipment were matched for body weight and assigned to one of four groups: young untreated $(n=4)$, young ALCAR-treated $(n=4)$, old untreated $(n=4)$, and old ALCAR-treated $(n=4)$. All animals were housed individually in standard Makrolon cages and had free access to food and water. The rats were kept under a reversed light-dark cycle (lights on between 2100 and 0900 ).

\section{Treatment}

Six weeks after the animals had been matched, the ALCAR. treated groups were given $50 \mathrm{mg} / \mathrm{kg} /$ day ALCAR, which was dissolved in a $0.1 \%$ solution of saccharine. The control groups received a comparable amount of saccharine solution $(10 \mathrm{ml} 0.1 \%$ per day). Four weeks after the treatment started, the rats were handled extensively on four successive days. Two weeks later the animals were tested in the $\mathrm{OF}^{-}$.

Behavioral testing was cartied out between 1000 and 1300 . The drinking bottles containing the solutions wert offered two hours before the OF test was performed. All animals consumed the total amount of the sweetened solutions within a few minutes. A drinking botle containing tap water was always present.

\section{Behavional Procedure}

The OF consisted of a square base $(100 \times 100 \mathrm{~cm})$ subdivided into 36 equal squares by black lines; the walls were $30 \mathrm{~cm}$ high. The floon was made of white Trespa and the four walls were made of transparent Plexiglas . Two red fluorescent tubes provided very dim illumination (about two lux) on the floor of the apparatus.

Immediately after a rat was placed in the centre of the $\mathrm{OF}$ the movements of the rat were scored. A crossing was scored as soon as the rat crossed a line with both hind legs. After each session the number of boli was counted. The number of lines crossed and the total time spent in the comer squares were recorded manually with an AIM 64-microcomputer. The experimenter sat in front of the OF. Testing was carried out on four consecutive days in liveminute sessions.

\section{Siatistical Analysis}

In order to enhance reliability, the data from the four sessions were aggregated as proposed by Ossenkopp and Mazmanian (13). Three measures of of behavior were subjected to statistical analysis: mean number of boli per day (the nnean number of boli were transformed to rank scores because of the frequent occurrence of zero scores, predominantly in young rats); the mean daily number of crossing of all squares; the mean time $(t)$ in seconds per session spent in the corner squares in seconds transformed to the natural logarithm

$$
\operatorname{Ln}\left[\left(t_{1}+t_{2}+t_{3}+t_{4}\right) / 4\right]
$$

(subscripts refer to day 1 through 4 of testing) in order to remove inhomogeneity.

Shipment effects were analysed in an age by treatment by shipment analysis of variance (ANOVA). The behavioral measures of animals of both shipments were the same (all F's involving main effect and interactions with shipment were not significant). Thus, the second shipment can be considered as a replication of the first one. The data for both shipments were therefore pooled.

As mentioned in the Introduction, age-related changes were andysed by comparing the untreated groups with tutests. The effects of the chronic ALCAR treatment were assessed within age groups by using $t$-tests. Age differences and treatment effects on the number of boli were analysed by Kruskal-Wallis one-way analysis of variance by ranks ( $\chi^{2}$-approximation).

\section{RESULTS AND DISCUSSION}

The treatment and control groups weighed the same after the data for both shipments had been pooled. The mean body weight (grams $\pm S E M)$ was 288.1 ( \pm 3.6$)$ for the untreated young rats, $290.5( \pm 4.5)$ for the ALCAR-treated young rats, $499.4( \pm 11.1)$ for the untreated old rats, and $515.7( \pm 9.8)$ for the ALCARtreated aged rats. At testing, 11 weeks after matching, the body weights were $379.6( \pm 10.4), 375.9( \pm 9.1), 507.1( \pm 12.3)$, and $515.0( \pm 17.5)$ grams, respectively. Thus, the young rats had gained weight; there was no indication that the ALCAR treatment affected the body weight. The weights of the aged rats were stable over the entire period from matching to testing.

The results of OF behavior are summarized in Table 1. Compared with the young untreated rats, the old untreated rats made fewer crossings, $t(14)=4.1, p<0.01$, spent more time in the conter squares, $f(14)=-2.7, p<0.05$, and defecated more, $x^{2}(1)=9.2, p<0.01$. Although it is tempting to conclude that aged rats react more emotionally than young rats when confronted with a novel enviromment, no attempt was made to interpret age differences in OF behavior because of the lack of data on the validity of these measures across ages. The decrease in ambulation in the old rats is quite similar to the value (ca. 30\%) reported by others for rats of the same strain (15).

Chronic treatment with ALCAR had no effect on the OF behavior of young rats. This result contrasts with the findings reported by Drago and coworkers (5). The results of the two studies, however, cannot be compared directly because of procedural differences. Drago et al. used acute injections (1 mg/kg, IP), while we used a chronic oral administration of ALCAR. Another procedural difference is that Drago and coworkers tested the rats using the OF procedure described by Weijnen and Slangen (17). In this procedure rats are tested for one day in a brightly lit circular arena. In our study rats were tested in a dimly lit square OF on four consecutive days, in order to enhance the reliability of the OF measures $(13,16)$.

Old ALCAR-treated rats made fewer crossings, $t(14)=2.30$, $p<0.05$, and spent more time in the corner squares, $t(14)=$ $-2.71, p<0.05$, than the old untreated animals. This suggests that the treatment increased the emotional reactivity of the old rats when they were exposed to a novel environment. No treatment effect, however, was found for the number of boll. An alternative explanation in terms of a change in peripheral motor function camnot be excluded, but is highly unlikely. If any, the expected effect of the ALCAR treatment would be to increase ambullation in 
TABLE $]$

MEAN NUMBER ( $\$$ SEM) OF BOLI (BETWEEN PARENTHESES: MEDIAN) MEAN NUMBER OF CROSSINGS OF ALL SQUARES AND THE AVERAGE TIME SPENT IN CORNER SOUARES (IN SEC AND TRANSFORMED TO THE NATURAL LOOARITHM OF UNTREATED AND ALCAR-TREATED YOUNG (5 MONTHS) AND AGED (26 MONTHS) MALE WISTAR RATS $(\mathrm{n}=8$ PER GROUP

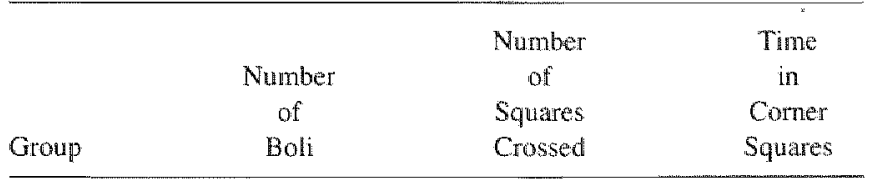

5 month old

\begin{tabular}{|c|c|c|c|}
\hline Untreated & $\begin{array}{c}0.06 \pm 0.06 \\
(0.0)\end{array}$ & $55.93 \pm 2.81$ & $4.75=0.05$ \\
\hline \multirow[t]{2}{*}{$\begin{array}{l}\text { ALCAR- } \\
\text { treated }\end{array}$} & $\begin{array}{c}0.28 \pm 0.20 \\
(0.0)\end{array}$ & $54.55=3.92$ & $4.75 \pm 0.07$ \\
\hline & $x^{2}=-1.06$ & $r=0.76$ & $r=-0.03$ \\
\hline \multicolumn{4}{|c|}{26 month old } \\
\hline Untrealed & $\begin{array}{c}2.81 \pm 0.63 \\
(3.0)\end{array}$ & $39.01 \pm 2.97$ & $4.93 \pm 0.05$ \\
\hline \multirow[t]{2}{*}{$\begin{array}{l}\text { ALCAR- } \\
\text { treated }\end{array}$} & $\begin{array}{c}3.19 \pm 1.03 \\
(2.9)\end{array}$ & $29.33=2.99$ & $5.10 \pm 0.04$ \\
\hline & $x^{2}=-0.31$ & 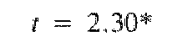 & $t=-2.71 *$ \\
\hline
\end{tabular}

*Treatment effect; $p<0.05$ the old rats as a result of the stimulatory effects of ALCAR on the energy and lipid metabolism of muscle cells [see (1) and (4)]. A similar argument holds with regard to a possible increase in arousal or exciability. According to Onofy al. (12). ALCARtreated rats show heightened arousal. An increase in ambulation would then be expected tather than the decrease observed.

In a recent studly we assessed the validity of the number of crossings and time spent in the comer squares of an of as measures of emotional teactivity (16). Young-adult rats of seven inbred strains were observed in the OF and a light-dak preference box. Both tests are supposed to measure emotional reactivity. Analysis by standard cross-yalidation techniques and by genetic correlations in an multitrait-mulimethod-like design revealed that the above-mentioned OF measures are valid measures of emotionality in the rat. This suggests that chronic treatment with ALCAR enhances the level of emotionality in aged rats. Such a notion does not readily fit into the supposed action of ALCAR on the responsiveness of the corticosterone system.

There are few studies on the influence of aging on emotionality (6). Old rats are less capable of terminating an adrenocortical stress response (14), but this has not been related to OF behavior as far as we know.

The possibility that emotionality is expressed differently in young and old rats is supported by the finding that diazepam does not have the usual anticonflict effect in the Geller-Seifter test when applied to old rats (11). Such findings underline the necessity to assess the walidity of the measures of motionallity in senescent rats, a study which we are currently carying out.

\section{ACKNOWLEDGHEMENTS}

We thank Sigmaw Taw Company for the partial tinancial support and for providing us with the acetyl-I-carniline. Finthermore, we thank Dr. Nancy Nicolson for her critical comments.

\section{REFERENCES}

1. Angelucci, L.; Ramacci, M. T. Acetyl-1-carnitine: neuropharmacological potentialities in the senescent rat. In: Shagass, C., et al, eds. Biological psychiatry. Developments in psychiatry, vol. 7. New York: Elsevier Science Publishing; 1986:1349-1351.

2. Badiali De Giorgi, L.; Bonvicini, F; Bianchi, D.; Bossoni, $G$. Laschi, $\mathbb{R}$. Ultrastructural aspects of ageing rat hippocampus and effects of l-acetyl-carnitime treatment. Drugs Exp. Clin. Res. 13; 185-189; 1987.

3. Broadhurst, P. L. Determinants of emotionality in the rat. I. Situa tionall factors. Br. J. Psychol. 48:1-12; 1957.

4. Curti, D.; Dagani, F.; Marzatico, F.; Benzi, G. Aging and acetylI-carnitine treatment: effects on some cerebral biochemical parameters. In: Shagass, C., et al, eds. Biological psychiatry. Developments in psychiatry. vol. 7. New York: Elsevier Science Publishing: 1986: 1343-1345.

5. Drago, F.; Continella, G.: Pennisi, G.; Alloro, M. C.; Calvani, M.; Scapagnini, U. Behavioral effects of acetyl-1-camitine in the male rat. Pharmacol. Biochem. Behav. 24:1393-1396; 1986.

6. Elias, M. F.; Elias, P. K. Motivation and aciivity. In: Birren, J. E.; Shaie, K. W. eds. Handbook of the psychology of aging. New York: Van Nostrand Reinhold Company; 1977:357-383.

7. Gage, F. H.; Dunnett, S. B.; Bjorkilund, A. Age-related impaiments in spatial memory are independent of those in sensorimotor skills. Neurobiol. Aging 10:347-352: 1989 .

8. Ghirardi, O.; Milano, S.; Ramacci, M. T.; Angelucci, L. Effect of acetyl-l-carnitine chronic treatment on discrimination models in aged rats. Physiol. Behav. 44:769-773; 1988

9. Goma, M.; Tobena, A. Reliability of warious measures obtained in open-field test. Psychol. Rep. 43:559-569; 1978.
10. Hal, C. S. Emotional behavior in the rat. III. The retationstip between emotionality and anbulatory activity. 1. Comp. Plysiol. Psychol. 22:345-352; 1936 .

11. Kominsky, H. L.; Buck. M. A.; Mundinger, K. L.; MeSwceney, th. K.; Farmer-Dougan. V. A ; Dougan, J. D. Elfects of aging on anticonflict and CNS depressant activity of diazepam in rats. Psychophamacology (Betin) 93:443-448; 1987

12. Onofrj, M.; Bodlis-Wollner, 1.; Pola, Pa; Calwan, M. Central cholin ergic effects of tevo-acetylcanitine. Drugs Exp. Clin. Res. 9:161169.1983

13. Ossenkopp, K. . P.; Mazmanian, D. S , The principle of aggregation in psychobiological corretational research: An example from the openfield test. Anim. Learn. Behaw, 13:339-344:; 1985.

14. Sapolsky, R.: Krey, L.: McEwen, B. The adrenoeorticall siressresponse in the aged male rat: impaniment of recovery from stress. Exp. Gerontol. 18:55-64: 1983.

15. Schuuman, T.; Traber, 1 . Old rats as an animal model for senile dementia: behavioural effects of mimodipine. In: Bergener, M.: Reisberg, B., edls. Diagnnosis and treatment of senile dementia. Berfin Springer Verlag: 1989:295-307

16. Van der Stady, F. I.; Kerbusch, S.; Ratijmakers, W. G. M. Genetic correlations in validating emotionality. Behav. Genet. 20:51-62;1990.

17. Weijnen, J. A. W. M.: Slangen, J. L. Effects of ACTH-analogues on extinction of conditioned behavior. In: de Wied, D.; Weinen, J.A. W. M., eds. Pituitary, adrenal and the brain. Amsterdam: Elsevier 1970:221-235. (Prog. Brain Res., vol. 3.)

18. Willig, F.; Palacios, A.; Monmaur, P.; MHarzi, M.; Laurent, Y.; Delacour, $Y$. Short-term memory, exploration and locomotor activity in aged rats. Netrobiol. Aging 8:393 -402; 1987. 